\title{
Does Dairy Liquid Manure Complementary to Mineral Fertilization Increase Grain Yield Due to Changes in Soil Fertility?
}

\author{
Gabriel Barth' \\ https://orcid.org/0000-0002-8669-0588 \\ Lenir Fátima Gotz ${ }^{2}$ \\ https://orcid.org/0000-0001-6145-4717 \\ Nerilde Favaretto ${ }^{2}$ \\ https://orcid.org/0000-0002-7405-8358 \\ Volnei Pauletti ${ }^{*}$ \\ https://orcid.org/0000-0002-9231-7851
}

${ }^{1}$ ABC Research Foundation, Soils and Plant Nutrition Department, Castro, Paraná, Brazil; ²Federal University of Paraná, Department of Soil Science and Agricultural Engineering, Curitiba, Paraná, Brazil.

Received: 2019.09.06; Accepted: 2019.12.12.

*Correspondence: vpauletti@ufpr.br, Tel.: +55 (41) 3350-5609 (V.P.)

HIGHLIGHTS

- Manure application in agricultural soils is common in livestock production regions.

- Dairy manure application increased the crop grain yield.

- Dairy manure even applied on soil surface provided chemical improvements in deep layers.

- Balance between the soil bases and the acidity is fundamental for maximum yield.

Abstract: The main destination of manure is the application to croplands near livestock farms as nutrient source to enhance crop production. The aim of this study was to define the dairy liquid manure (DLM) dose, complementary to the mineral fertilizer, for higher crops yield, in rotation black oat-maize-wheat-soybean, and to identify the soil chemical variables improved by the manure that most affect the yield, in long-term. The experiment was conducted from 2006 to 2015, in no-tillage system, at Paraná State, Brazil. The soil was a Latossolo Bruno Distrófico típico, clayey texture. The treatments consisted by doses of DLM (0,60, 120 and $180 \mathrm{~m}^{3}$ ha $^{-1}$ year $^{-1}$ ), complementary to the mineral fertilizer (applied in the same amount for all DLM doses). Crops yield and soil chemical variables were evaluated at six depths $(0-10 ; 10-20 ; 20-30 ; 30-40 ; 40-$ 50 and 50-60 cm). The DLM application increased the yield of all crops, but not in all harvests. The DLM even applied at soil surface improved the soil chemical variables in deep layers, resulting in high positive 
correlation between yield and exchange bases, $\mathrm{P}, \mathrm{Zn}$ and $\mathrm{Mn}$ contents, and high negative correlation with $\mathrm{Ca} / \mathrm{Mg}$ ratio and potential acidity at depth $0-10 \mathrm{~cm}$. The DLM dose, complementary to the mineral fertilization, that provided higher soybean and wheat yield was about $130 \mathrm{~m}^{3} \mathrm{ha}^{-1}$ year ${ }^{-1}$, while for maize this dose was equal to or greater than $180 \mathrm{~m}^{3} \mathrm{ha}^{-1}$ year $^{-1}$. This effect was not attributed to a single chemical variable but the improvement of all chemical variables evaluated.

Keywords: organic fertilizer; no-tillage; Zea mays; Glycine max; Triticum aestivum; Avena strigosa.

\section{INTRODUCTION}

The Brazilian livestock sector stands out in the world ranking, presenting the third largest herd of dairy cows (approximately 20 million cows milked in 2016). In relation to the milk production, Brazil occupies the fifth position, and, Paraná state, Southern Brazil, is the second largest national milk producer, with $14.1 \%$ of production in 2016 [1]. When the livestock production is based on intensive confinement system, it results in large volumes of manure, which the main destination is the application in croplands. The benefits of applying manure to agriculture are worldwide known. Manure application improves chemical, physical and biological soil properties, and consequently, crop growth and yield, either alone or in association with mineral fertilizers [2-7].

The increasing of the world population requires increases in food production. Thus, in order to preserve the environment and the natural resources, the increases in food production must be accompanied by adequate fertilization management. In intensive milk production systems, most producers apply high rates of manure, associated with mineral fertilization, without considering the amount of nutrients applied $[3,8]$. The application of manure is usually near to the livestock farm, due to the high transportation cost. It is known that improper use of manure can cause surface and groundwater pollution. Thus, the key to a proper manure management is to balance application rates with crop nutrient needs [9].

In this context, studies should be carried out to help farmers on recommendations of best management practices to reach a sustainable agriculture. In addition, results from long-term experiments are very important to optimize applications, to maximize agricultural production and to minimize environmental impacts such as the water pollution $[2,10]$. Based on that, this study was conducted in a long-term experiment under no-tillage system with application on the soil surface of dairy liquid manure (DLM) complementary to the mineral fertilizer to define the best DLM dose for higher crops yield, and to identify the soil chemical variables improved by the manure that most affect the yield.

\section{MATERIAL AND METHODS}

The experiment was conducted at experimental station of the $A B C$ Research Foundation, located at Castro (24⒌ $51^{\prime} 50^{\prime \prime} \mathrm{S}, 49^{\circ} 56^{\prime} 25^{\prime \prime} \mathrm{W}, 1027 \mathrm{~m}$ altitude). The soil of the area, clayey texture with $10 \%$ slope, was classified as Latossolo Bruno Distrófico típico according to Brazilian Soil Classification System (SiBCS) [11], which corresponding to Oxisol in the American Soil Taxonomy System. The regional climate is classified as $\mathrm{Cfb}$-humid subtropical climate mesothermal (Köppen), with mild summers and an average annual rainfall of $1,554 \mathrm{~mm}$, without a dry season [12].

The installation of the experiment was in May 2006, in an area where no-tillage system had been practiced for more than 15 years. The treatments consisted of four annual rates of DLM $\left(0,60,120,180 \mathrm{~m}^{3}\right.$ $\mathrm{ha}^{-1}$ year $^{-1}$ ). The experimental design was a randomized complete block design, with four replications, and plots were $29.8 \mathrm{~m}^{2}(3.5 \mathrm{~m}$ by $8.5 \mathrm{~m})$. Each annual DLM rate was applied on the soil surface, without incorporation, and split into two applications: half in the winter crop and half in the summer crop. The soil properties are presented in Table 1 (adapted from [13]). 
Table 1. Chemical properties and particle size distribution of the soil before the beginning of the experiment $(0-10,10-$ 20 and $20-30 \mathrm{~cm}$ ).

\begin{tabular}{|c|c|c|c|c|c|c|c|c|c|c|c|}
\hline $\mathrm{pH}$ & $O C^{(1)}$ & $\mathrm{H}+\mathrm{Al}$ & $\mathrm{Ca}$ & Mg & K & CEC $^{(2)}$ & Al & $\mathbf{P}^{(3)}$ & Clay & Sand & Silt \\
\hline $\mathrm{CaCl}_{2}$ & $\mathrm{~g} \mathrm{~kg}^{-1}$ & \multicolumn{6}{|c|}{$\mathrm{cmolc} \mathrm{kg}^{-1}$} & $\mathrm{mg} \mathrm{kg}^{-1}$ & \multicolumn{3}{|c|}{$\mathrm{g} \mathrm{kg}^{-1}$} \\
\hline \multicolumn{12}{|c|}{$0-10 \mathrm{~cm}$} \\
\hline 5.4 & 29.3 & 4.6 & 5.6 & 1.7 & 0.30 & 12.2 & 0.0 & 5.5 & 691 & 195 & 114 \\
\hline \multicolumn{12}{|c|}{$10-20 \mathrm{~cm}$} \\
\hline 5.3 & 22.0 & 4.6 & 4.5 & 1.0 & 0.16 & 10.1 & 0.0 & 2.5 & 712 & 179 & 109 \\
\hline \multicolumn{12}{|c|}{$20-30 \mathrm{~cm}$} \\
\hline 5.4 & 19.0 & 4.0 & 3.9 & 0.8 & 0.10 & 8.8 & 0.0 & 1.0 & 725 & 99 & 176 \\
\hline
\end{tabular}

(1) OC: organic carbon; (2) CEC: cation exchange capacity; (3) P- Mehlich-1.

The dry matter and N, P and K content of the DLM applied since the beginning of the experiment (20062015 ) are presented in Table 2 (adapted from $[8,14]$ ). The amount of N, P and K (annual average for winter plus summer crops) applied by DLM were: 122,39 and $169 \mathrm{~kg} \mathrm{ha}^{-1}$ year $^{-1} ; 244,79$ and $338 \mathrm{~kg} \mathrm{ha}^{-1} \mathrm{year}^{-1}$ and; 367,118 and $508 \mathrm{~kg} \mathrm{ha}^{-1}$ year ${ }^{-1}$ for the doses 60,120 and $180 \mathrm{~m}^{3} \mathrm{ha}^{-1}$ year-1, respectively. The DLM, a material constituted of feces, urine and water of cleaning, stored in lagoons, came from a farm with the production based on a free stall system of holstein cows. Besides DLM, mineral fertilizers (NPK) were applied (with the exception of black oat crop) in the same amount for all treatments following the soil test and grain crop needs [15]. The amount of N, P and K applied in the different harvests (winter/summer) via mineral fertilization from year 2006-2015 are presented in Table 3 [14]. Mineral fertilization was performed with NPK formulations in-furrow at sowing and with simple fertilizers (urea and $\mathrm{KCl}$ ) in top-dressing. The average amount for N, P and K, respectively, applied to maize crop was 174, 39 and $70 \mathrm{~kg} \mathrm{ha}^{-1}$, to soybean crop was 0, 25 and $48 \mathrm{~kg} \mathrm{ha}^{-1}$ and to wheat crop was 122, 30 and $55 \mathrm{~kg} \mathrm{ha}^{-1}$. In May 2007 and Aug 2013 liming was carried out using 2,500 and $1,900 \mathrm{~kg} \mathrm{ha}^{-1}$ of dolomitic limestone, respectively.

Table 2. Chemical properties of the dairy liquid manure (DLM) applied from year 2006-2015 for the experimental area.

\begin{tabular}{|c|c|c|c|c|c|c|c|}
\hline \multirow[t]{2}{*}{ Date } & \multirow{2}{*}{$\begin{array}{c}\text { Dry matter } \\
\mathrm{g} \mathrm{L}^{-1}\end{array}$} & \multicolumn{2}{|c|}{$\mathbf{N}$} & \multicolumn{2}{|c|}{$\mathbf{P}$} & \multicolumn{2}{|c|}{ K } \\
\hline & & $\mathrm{g} \mathrm{L}^{-1}$ & $\mathrm{~kg} \mathrm{~m}^{-3}$ & $\mathrm{~g} \mathrm{~L}^{-1}$ & $\mathrm{~kg} \mathrm{~m}^{-3}$ & $\mathrm{~g} \mathrm{~L}^{-1}$ & $\mathrm{~kg} \mathrm{~m}^{-3}$ \\
\hline May-06 & 90.5 & 1.82 & 0.91 & 0.77 & 0.39 & 3.46 & 0.39 \\
\hline Oct-06 & 75.5 & 1.74 & 0.87 & 0.61 & 0.31 & 2.35 & 0.31 \\
\hline May-07 & 43.3 & 0.95 & 0.48 & 0.41 & 0.21 & 1.48 & 0.21 \\
\hline Nov-07 & 89.6 & 2.02 & 1.01 & 0.72 & 0.36 & 3.04 & 0.36 \\
\hline Aug-08 & 87.1 & 1.75 & 0.88 & 0.61 & 0.31 & 2.85 & 0.31 \\
\hline Jan-09 & 46.7 & 1.10 & 0.55 & 0.32 & 0.16 & 1.57 & 0.16 \\
\hline Aug-09 & 51.0 & 0.94 & 0.47 & 0.56 & 0.28 & 1.20 & 0.28 \\
\hline Nov-09 & 44.9 & 2.60 & 1.30 & 0.92 & 0.46 & 1.91 & 0.46 \\
\hline Jul-10 & 85.5 & 1.56 & 0.78 & 0.70 & 0.35 & 3.22 & 0.35 \\
\hline Jan-11 & 93.1 & 1.74 & 0.87 & 0.84 & 0.42 & 4.14 & 0.42 \\
\hline Aug-11 & 113.0 & 2.29 & 1.15 & 0.83 & 0.42 & 4.19 & 0.42 \\
\hline Nov-11 & 94.0 & 1.85 & 0.93 & 0.69 & 0.34 & 3.71 & 0.34 \\
\hline Aug-12 & 87.3 & 2.23 & 1.11 & 0.65 & 0.33 & 4.09 & 0.33 \\
\hline Jan-13 & 73.7 & 1.56 & 0.78 & 0.54 & 0.27 & 0.13 & 0.27 \\
\hline Jun-13 & 79.1 & 1.66 & 0.83 & 0.61 & 0.31 & 3.91 & 0.31 \\
\hline Nov-13 & 71.1 & 1.44 & 0.72 & 0.43 & 0.22 & 3.27 & 0.22 \\
\hline Jul-14 & 94.5 & 5.20 & 2.60 & 0.87 & 0.44 & 2.74 & 0.44 \\
\hline Jan-15 & 91.4 & 4.20 & 2.10 & 0.70 & 0.35 & 3.49 & 0.35 \\
\hline Average & 78.4 & 2.04 & 18.33 & 0.65 & 5.88 & 2.82 & 5.88 \\
\hline Standard(1) & 69.0 & 1.56 & 1.02 & 0.55 & 0.33 & 2.80 & 0.33 \\
\hline
\end{tabular}

(1) The standard is the average was presented of dairy liquid manure collected in Paraná State [14]. 
Table 3. Amount of nitrogen $(N)$, phosphorus $(P)$ and potassium $(K)$ applied in the different harvests (winter/summer) via mineral fertilization from year 2006-2015.

\begin{tabular}{|c|c|c|c|c|}
\hline \multirow{2}{*}{ Crop } & \multirow{2}{*}{ Harvest } & $\mathbf{N}$ & $\mathbf{P}$ & K \\
\hline & & \multicolumn{3}{|c|}{$\mathrm{kg} \mathrm{ha}^{-1}$} \\
\hline Black oat & 2006 & 0 & 0 & 0 \\
\hline Maize & $2006 / 07$ & 175 & 37 & 93 \\
\hline Black oat & 2007 & 0 & 0 & 0 \\
\hline Soybean & $2007 / 08$ & 0 & 26 & 50 \\
\hline Wheat & 2008 & 114 & 39 & 59 \\
\hline Soybean & $2008 / 09$ & 0 & 22 & 42 \\
\hline Black oat & 2009 & 0 & 0 & 0 \\
\hline Maize & $2009 / 10$ & 175 & 41 & 63 \\
\hline Wheat & 2010 & 134 & 30 & 63 \\
\hline Soybean & $2010 / 11$ & 0 & 26 & 50 \\
\hline Black oat & 2011 & 0 & 0 & 0 \\
\hline Maize & $2011 / 12$ & 165 & 39 & 50 \\
\hline Wheat & 2012 & 120 & 26 & 50 \\
\hline Soybean & $2012 / 13$ & 0 & 26 & 50 \\
\hline Black oat & 2013 & 0 & 0 & 0 \\
\hline Maize & $2013 / 14$ & 183 & 41 & 75 \\
\hline Wheat & 2014 & 120 & 26 & 50 \\
\hline Soybean & $2014 / 15$ & 0 & 26 & 50 \\
\hline Total & & 1,186 & 405 & 745 \\
\hline
\end{tabular}

The experiment was carried out in no-tillage system, during nine agricultural years, between 2006 and 2015, with crop rotation constituted of black oat (Avena strigosa Schreb.) and wheat (Triticum aestivum L.) in the winter and soybean (Glycine $\max$ (L.) Merr.) and maize (Zea mays L.) in the summer. Row spacings were $0.8,0.4$ and $0.17 \mathrm{~m}$ for maize, soybean and winter crops (wheat and black oat), respectively. Grain yield and dry matter yield was determined by harvesting 14 rows of $2 \mathrm{~m}$ in winter crops and 8 rows of $2 \mathrm{~m}$ in summer crops. Grain weight was corrected to $13 \%$ humidity and values were converted to $\mathrm{kg} \mathrm{ha}^{-1}$.

Thus, five black oat, four wheat, four maize and five soybean harvests were evaluated. Data from each harvest and also from the average were analyzed. Besides, accumulated grain yield for maize, soybean and wheat was calculated by adding the subsequent harvest of the each crop, and also it was evaluated the total accumulated grain yield by adding all grain harvests of the period, totaling 13 harvests.

In July 2014 , soil samples were collected at six depths $(0-10 ; 10-20 ; 20-30 ; 30-40 ; 40-50 ; 50-60 \mathrm{~cm})$ with the aid of an auger sampler. Each sample was composed by ten subsamples. All soil samples were air-dried and sieved through a 2-mm mesh sieve. Soil pH was determined in a $0.01 \mathrm{~mol} \mathrm{~L}^{-1} \mathrm{CaCl}_{2}$ suspension $(1: 2.5$ $\mathrm{v} / \mathrm{v}$ soil/solution); potential acidity $(\mathrm{H}+\mathrm{Al})$ was estimated after $\mathrm{pH}$ reading with the addition of SMP buffer solution to soil samples, using correlation with SMP index [17]; organic carbon was determined by the colorimetric method and organic matter carbon was calculated multiplying the organic carbon content by 1.724; soil phosphorus was extracted using anion exchange resin; calcium, magnesium and potassium was extracted using cation exchange resin [15]. Based on these results, the calcium/magnesium ratio, base saturation and cation exchange capacity (CEC) were calculated.

The results were submitted to analysis of variance and regression equations. The means of soil chemical variables were compared by the Tukey test at the $5 \%$ probability level. Principal component analysis was carried out using accumulated grain yield data (maize, soybean, wheat and total) and soil chemical variables at depth 0-10 cm. The software $R$ was used.

\section{RESULTS AND DISCUSSION}

\section{Crops yield}

The DLM application linearly increased maize grain yield in the 2006/07, 2009/10 and average harvests (Figure 1a), being 13\%, 13\% and 10\% higher, respectively, with the application of $180 \mathrm{~m}^{3} \mathrm{ha}^{-1}$ year-1 compared to the control. On the other hand, the DLM application did not influence the maize yield in the 2011/12 and 2013/14 harvests (Figure 1a). The increase in maize grain yield may be related to the additional $\mathrm{N}$ supplied by the manure, suggesting that the added mineral $\mathrm{N}\left(175 \mathrm{~kg} \mathrm{ha}^{-1}\right.$ in both harvests) was not enough 
to obtain the maximum crop potential. However, in the 2011/12 and 2013/14 harvests, the N supplied by the mineral source may have been enough, reducing the effects of manure [18]. In addition, the higher response of maize at the beginning of the experiment may be due to the low $P$ content in the area before to the installation of the experiment (Table 1) [16], thus, the additional supply of P by DLM may have contributed to the increase of crop yield, evidenced by the strong positive correlation between $\mathrm{P}$ content and average maize yield $(r=0.82)$. Other papers have found similar results, associating organic fertilizers with mineral fertilizers, attributing increased yield to higher nutrient availability and, consequently, greater extraction by plants $[7,19,20]$.

For soybean, in the 2010/11 harvest, the DLM application linearly increased the grain yield (Figure 1b), with $11 \%$ increment. On the other hand, for other harvests, the DLM not improved the soybean grain yield. The average of all harvests increased with DLM application, adjusting to a second degree polynomial function (Figure $1 \mathrm{~b}$ ), and the estimated dose for maximum yield was $126 \mathrm{~m}^{3} \mathrm{ha}^{-1}$ year ${ }^{-1}$ (9\% increment). Other studies also found increased soybean yield by combining organic and mineral fertilizer $[9,21,22]$.

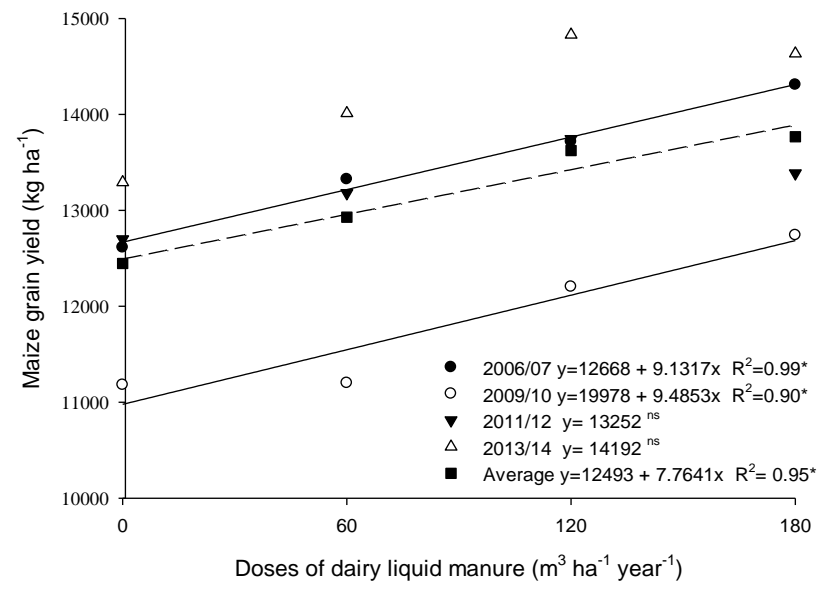

(a)

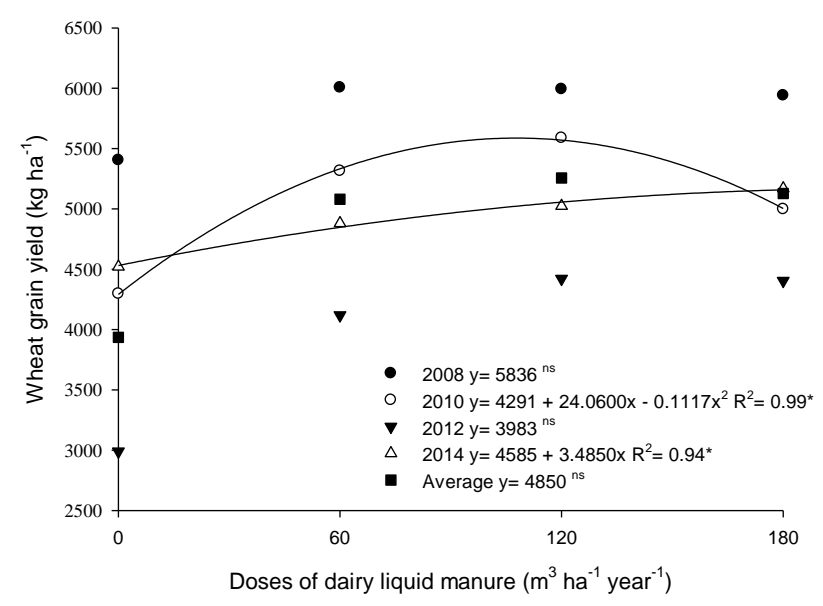

(c)

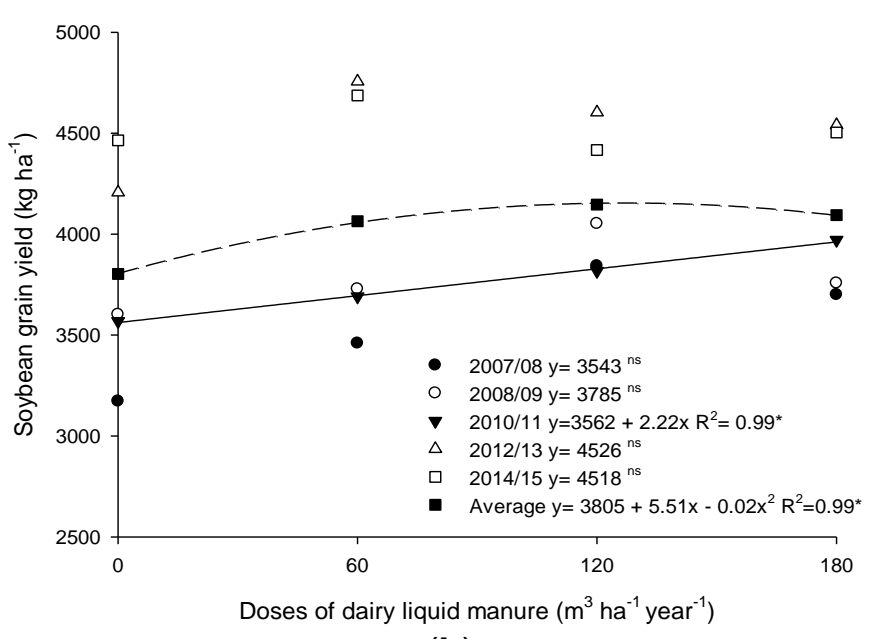

(b)

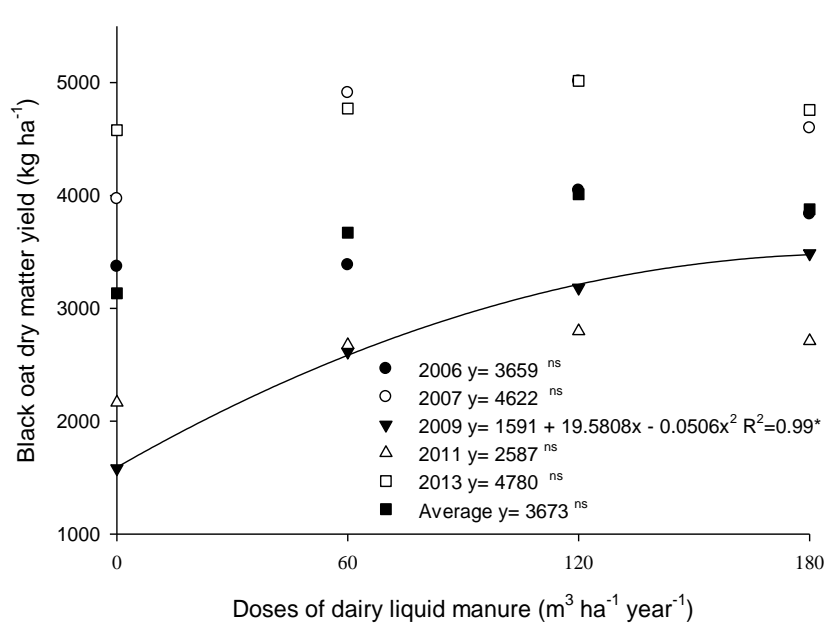

(d) 


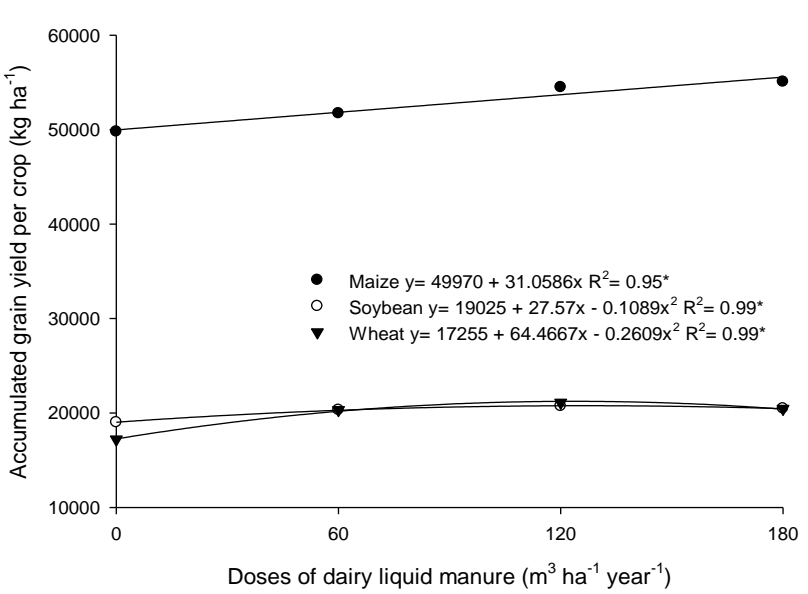

(e)

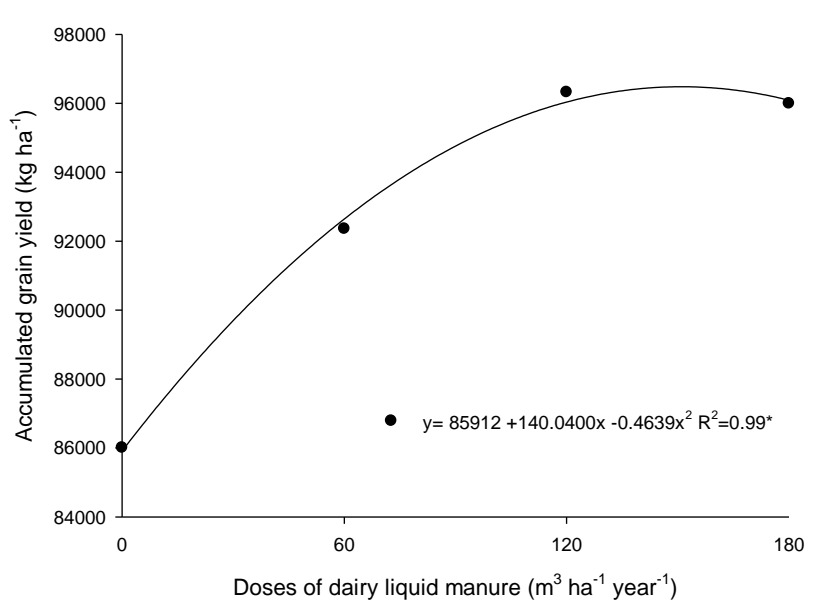

(f)

Figure 1. Maize (a), soybean (b), wheat (c) and black oat (d) yield per harvest and average of harvests; accumulated grain yield per crop (e) and total accumulated grain yield (maize+soybean+wheat) in the period 2006-2015 (f) as a function of dairy liquid manure (DLM) doses $\left(0,60,120\right.$ and $180 \mathrm{~m}^{3}$ ha $^{-1}$ year-1 $\left.^{-1}\right)$ in no-tillage system, in Castro-Paraná.

Relative to winter crops, the wheat grain yield increased with DLM application in 2010 and 2014 harvests. On the other hand, in the other harvests and in the average of harvests there was no effect of manure application (Figure 1c). In the 2010 harvest, the estimated dose for maximum wheat yield was $108 \mathrm{~m}^{3} \mathrm{ha}^{-1}$ year $^{-1}$, with 30\% increment compared to the control treatment, however in the 2010 and 2014 harvests, the increment was only $14 \%$. In agreement with these data, other authors $[20,23]$ observed that the association of mineral fertilizer with manure increased wheat yield. About the black oat, the DLM application increased the dry matter only in the 2009 harvest, with 120\% increment (Figure 1d). The lower response of black oat may be due to $\mathrm{N}$ supply from the predecessor crop (soybean) [18]. However, as previously described, in the 2009 harvest, the black oat dry matter yield was improved by DLM application; the dry matter yield in the control treatment in the 2009 harvest was very low $\left(1,581 \mathrm{~kg} \mathrm{ha}^{-1}\right)$ compared to the average of the control treatment of other harvests $\left(3,521 \mathrm{~kg} \mathrm{ha}^{-1}\right)$. The lower yield in 2009 probably was associated with factors such as precipitation, temperature, solar radiation and diseases. Thus, the improvement of soil physical, chemical and biological properties with manure application may have compensated this adverse condition, favoring plant development and, consequently, its dry matter yield.

The DLM application in the nine-year period showed great variation on crop yield among the harvests. One reason could be the great variation of the manures applied in the nine-year period in each crop season (Table 2), as well as weather conditions that may vary, influencing the response of the application [24].

Regarding to the accumulated grain yield of each crop, there was a linear increase for maize (10\%) and quadratic increase for soybean $(9 \%)$ and wheat $(23 \%)$ (Figure 1e). The estimated dose for maximum yield was $127 \mathrm{~m}^{3}$ ha $^{-1}$ year $^{-1}$ and $123 \mathrm{~m}^{3}$ ha $^{-1}$ year $^{-1}$, for soybean and wheat respectively. The linear response of maize, even with low increment (10\%) and higher response of wheat with $23 \%$ increment, species of the Poaceae family, is explained by the additional supply of $\mathrm{N}$ with manure application. The higher addition of nitrogen by mineral fertilizer in the maize crop compared to the wheat crop may explain the lower increment of maize with manure application. Also, the lower maize yield increment compared to wheat may be associated with plant lodging by excessive $\mathrm{N}$ inputs [25]. The soybean resulted in lower response $(9 \%$ increment), possibly because in this crop the $N$ is supplied via biological fixation [18]. However, the other benefits by manure application improved the soybean grain yield up to $127 \mathrm{~m}^{3} \mathrm{ha}^{-1}$ year-1 DLM. The higher response of maize and wheat in relation to soybean has been observed with application of swine manure doses [21].

The total accumulated grain yield (all crops) in the nine-year period (2006-2015) increased up to $151 \mathrm{~m}^{3}$ ha $^{-1}$ year $^{-1}$ DLM dose (Figure 1f), resulting in 12\% increment compared to the control treatment (without DLM application). Combining mineral and organic fertilizers, the nutrients are slowly but continuously supplied reaching the need for crops. Also, there is the supply of readily available macro and micronutrients, resulting in better growth and grain yield [23]. Beyond the chemical aspect, the better crop yield with the balanced application of organic and mineral fertilizer can be attributed to improvements in soil physical and biological properties $[5,6,19,26]$. The integrated use of manure with mineral fertilizers increased soybean and wheat 
yield, which provided stability in production compared to the use of only mineral fertilizer [26]. The same authors highlighted that the beneficial effect of integrated use of mineral fertilizer with manure was more pronounced and effective in increasing yield as the cultivation year progressed.

\section{Soil fertility}

After nine-year period of fertilization, the DLM application influenced all soil chemical variables evaluated (Figure 2). The DLM application increased the soil active acidity $(\mathrm{pH})$ and reduced the potential acidity $(\mathrm{H}+\mathrm{Al})$ up to $20 \mathrm{~cm}$ depth, evidencing the alkalizing effect of this product (Figure 2a,b) possibly due to the presence of carbonates and bicarbonates, that are added to animal feed and excreted in manure. In addition, other compounds such as organic acids from the carboxyl and phenolic hydroxyl groups also have an important role in buffering soil acidity and increasing soil $\mathrm{pH}$ [27].

For each $\mathrm{m}^{3}$ of manure applied annually, there was an average increase of 0.0043 and 0.0040 units in the $\mathrm{pH}$ scale after nine years of application, at depths $0-10$ and $10-20 \mathrm{~cm}$, respectively (Table 4). At depth 0$5 \mathrm{~cm}$, [28] observed for each $\mathrm{m}^{3}$ of bovine manure applied annually, average linear increase of 0.0047 units in $\mathrm{pH}$ after six years of application. The effect of DLM application on the depth acidity correction was also observed with the successive application of swine manure doses [29,30].

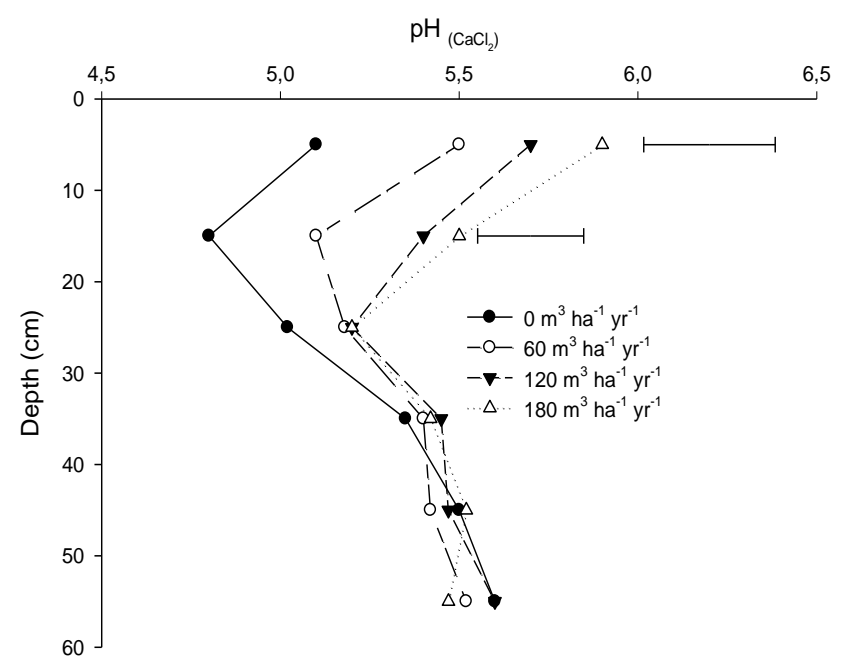

(a)

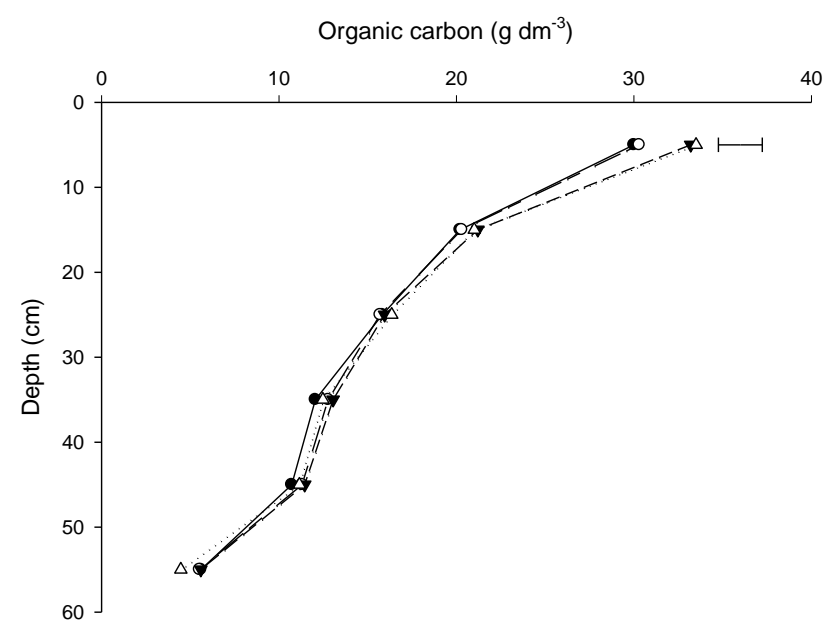

(c)

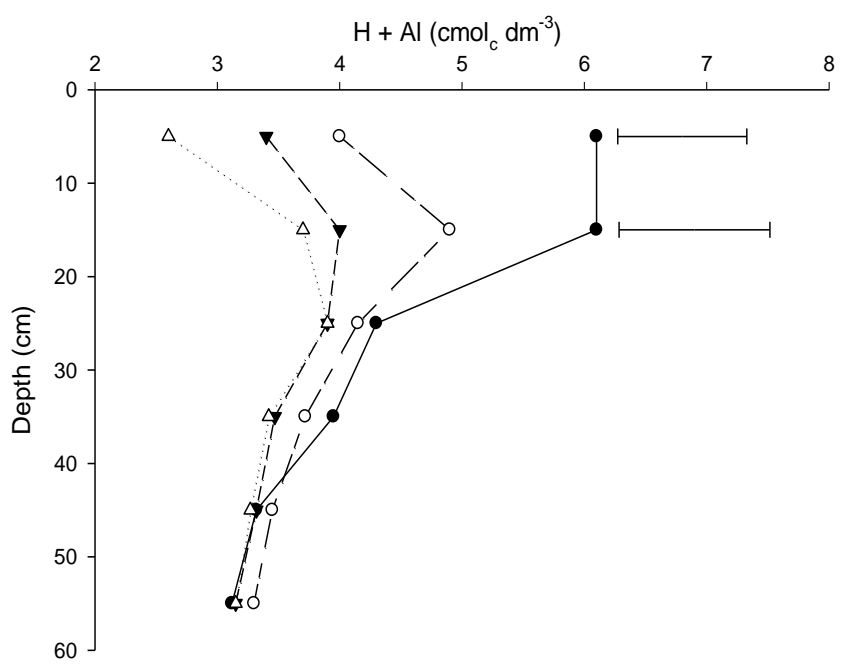

(b)

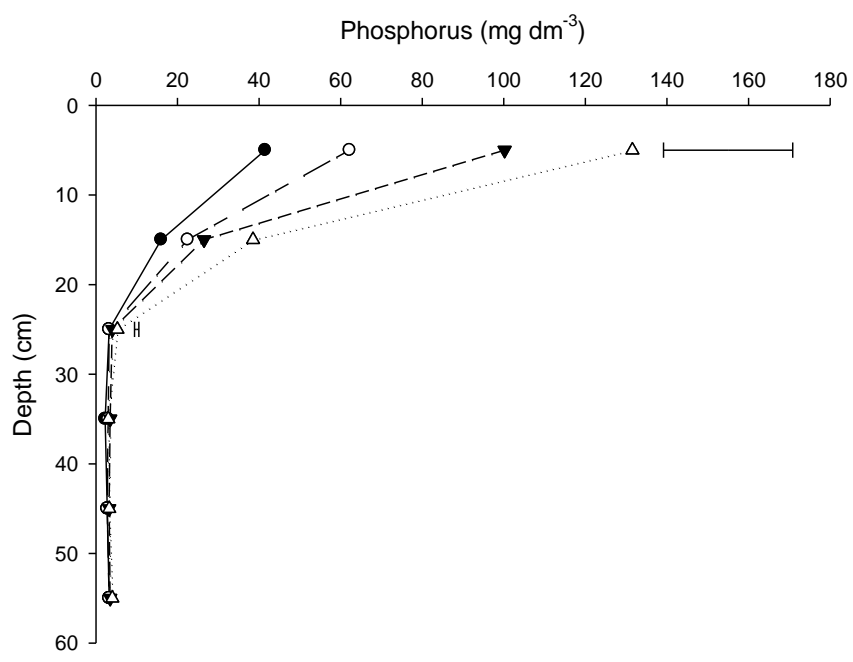

(d) 


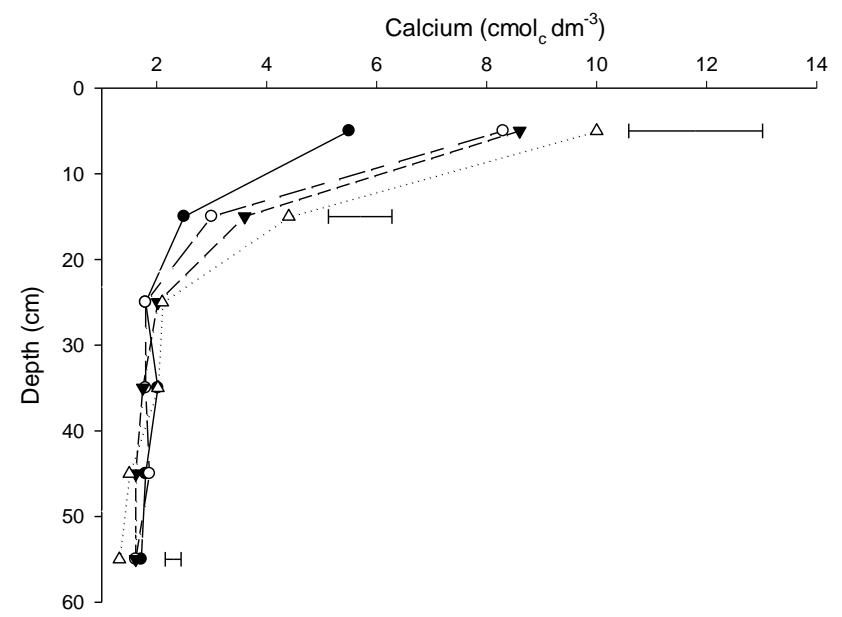

(e)

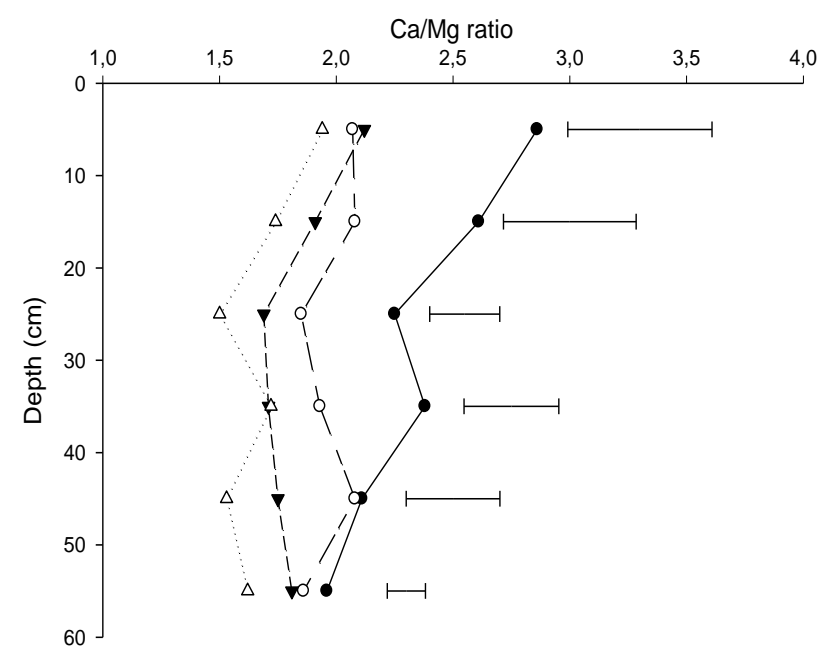

(g)

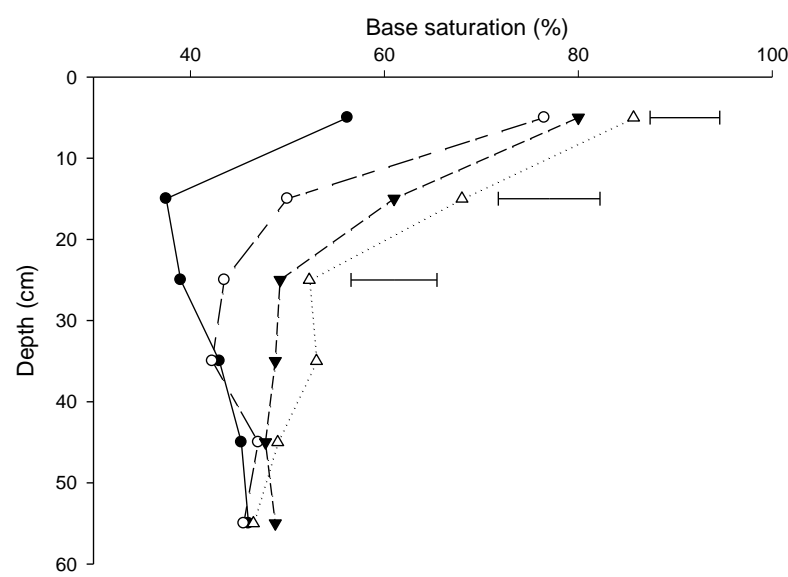

(i)

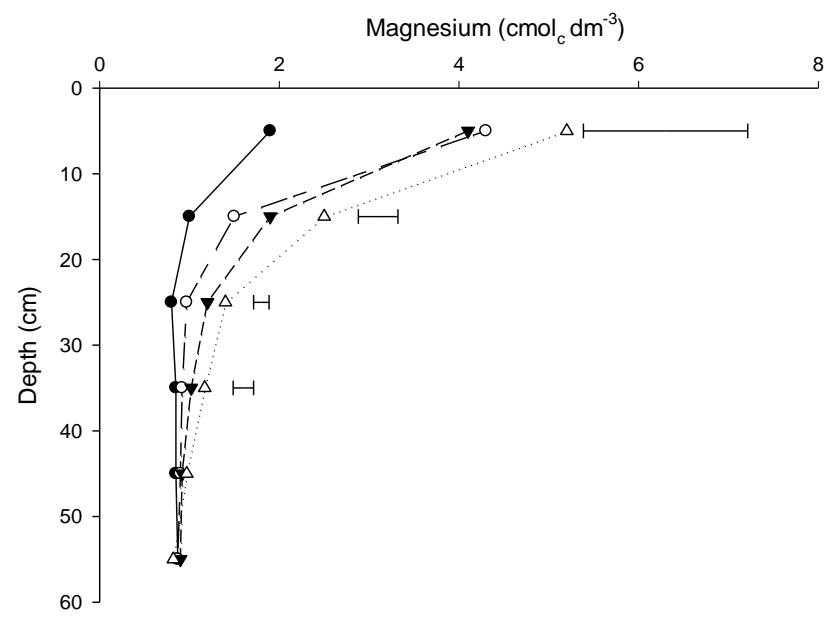

(f)

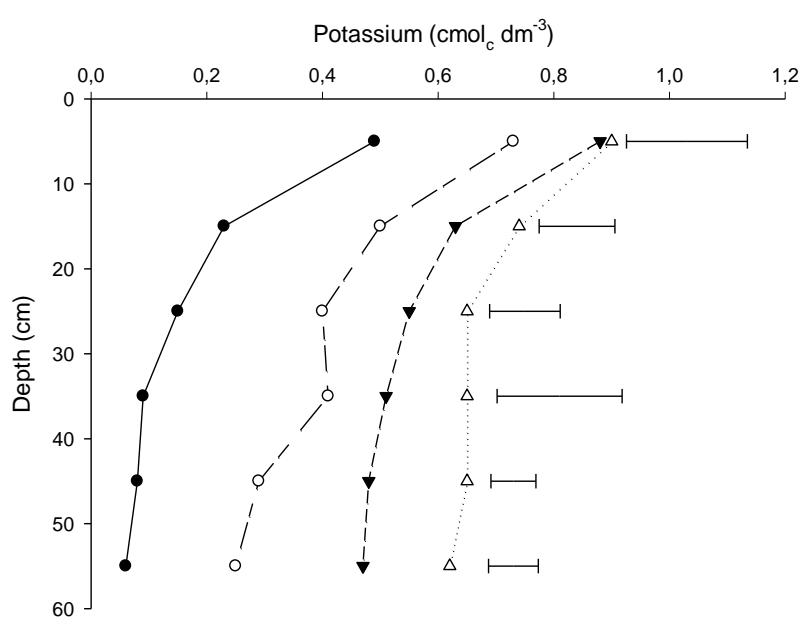

(h)

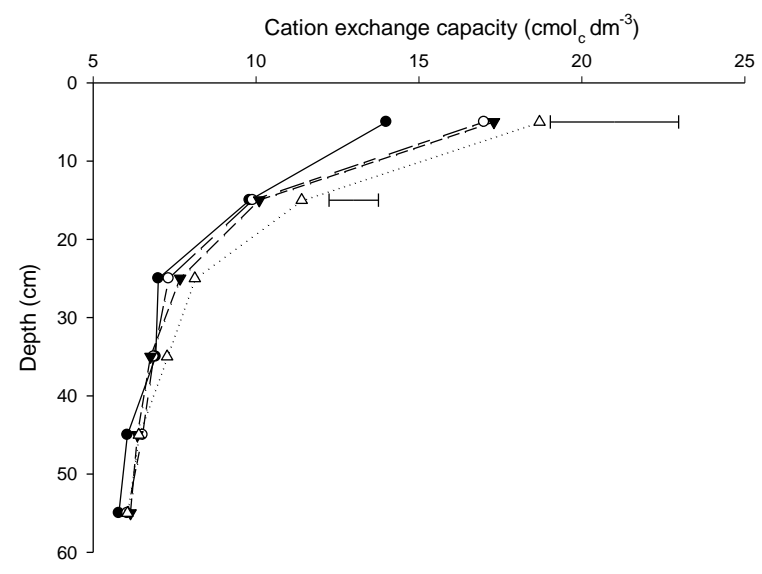

(j)

Figure 2. $\mathrm{pH}$ in $\mathrm{CaCl}_{2}(\mathbf{a})$, potential acidity $(\mathrm{H}+\mathrm{Al})(\mathbf{b})$, contents of organic carbon (c), phosphorus (resin) (d), calcium $(\mathbf{e})$, magnesium $(\mathbf{f})$, calcium/magnesium ratio $(\mathbf{g})$, potassium $(\mathbf{h})$, base saturation (i), cation exchange capacity (j) at six depths of a Latossolo Bruno Distrófico típico, after nine years of dairy liquid manure (DLM) application at doses of 0, 60,

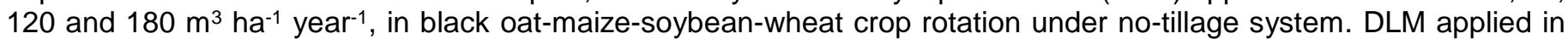
each crop season since May 2006. Soil sampled in July 2014. (Tukey DMS, $p<0.05$ ). 
Table 4. Regression equations for $\mathrm{pH}$ in $\mathrm{CaCl}_{2}$, phosphorus $(\mathrm{P})$, calcium $(\mathrm{Ca})$, magnesium $(\mathrm{Mg})$, potassium $(\mathrm{K})$ and base saturation (V\%) in soil depth after nine years of dairy liquid manure (DLM) application at doses of 0,60, 120 and $180 \mathrm{~m}^{3} \mathrm{ha}^{-1}$ year-1, in a Latossolo Bruno Distrófico típico under no-tillage system, in black oat-maize-wheat-soybean crop rotation. DLM applied in each crop season since May 2006. Soil sampled in July 2014.

\begin{tabular}{|c|c|c|c|c|}
\hline \multirow{2}{*}{ Variable } & \multicolumn{4}{|c|}{ Regression equations } \\
\hline & $0-10 \mathrm{~cm}$ & $\mathbf{R}^{2}$ & $10-20 \mathrm{~cm}$ & $\mathbf{R}^{2}$ \\
\hline $\mathrm{pH}$ & $y=5.160+0.0043 x$ & $0.95^{*}$ & $y=4.840+0.0040 x$ & $0.94^{*}$ \\
\hline$P$ & $y=37.650+0.5133 x$ & $0.98^{*}$ & $y=15.150+0.1192 x$ & $0.95^{*}$ \\
\hline $\mathrm{Ca}$ & $y=6.030+0.0230 x$ & $0.84^{*}$ & $y=2.430+0.0105 x$ & $0.98^{*}$ \\
\hline $\mathrm{Mg}$ & ns & & $y=0.935+0.0085 x$ & $0.99^{*}$ \\
\hline $\mathrm{K}$ & $y=0.543+0.0023 x$ & $0.88^{*}$ & $y=0.276+0.0028 x$ & $0.95^{*}$ \\
\hline \multirow[t]{2}{*}{$\mathrm{V}(\%)$} & ns & & $y=38.750+0.1708 x$ & $0.98^{*}$ \\
\hline & $20-30 \mathrm{~cm}$ & $\mathbf{R}^{2}$ & $30-40 \mathrm{~cm}$ & $\mathbf{R}^{2}$ \\
\hline $\mathrm{pH}$ & ns & & $\mathrm{ns}$ & \\
\hline $\mathrm{P}$ & ns & & ns & \\
\hline $\mathrm{Ca}$ & ns & & ns & \\
\hline $\mathrm{Mg}$ & $y=0.788+0.0034 x$ & $0.99^{*}$ & $y=0.831+0.0018 x$ & $0.97^{*}$ \\
\hline $\mathrm{K}$ & $y=0.190+0.0028 x$ & $0.96^{*}$ & $y=0.148+0.0030 x$ & $0.93^{*}$ \\
\hline \multirow{2}{*}{ V $(\%)$} & $y=39.17+0.00758 x$ & $0.99^{*}$ & ns & \\
\hline & $40-50 \mathrm{~cm}$ & $\mathbf{R}^{2}$ & $50-60 \mathrm{~cm}$ & $\mathbf{R}^{2}$ \\
\hline $\mathrm{pH}$ & ns & & 年 & \\
\hline$P$ & ns & & $\mathrm{ns}$ & \\
\hline $\mathrm{Ca}$ & ns & & ns & \\
\hline $\mathrm{Mg}$ & $y=0.853+0.0006 x$ & $0.97^{*}$ & ns & \\
\hline $\mathrm{K}$ & $y=0.090+0.0032 x$ & $0.99^{*}$ & $y=0.065+0.0032 x$ & $0.99^{*}$ \\
\hline V (\%) & $y=45.45+0.0200 x$ & $0.98^{*}$ & $\mathrm{~ns}$ & \\
\hline
\end{tabular}

* significant at $5 \%$; ns: not significant at $5 \%$.

As expected, the DLM application reduced soil potential acidity $(\mathrm{H}+\mathrm{Al})$ up to $10-20 \mathrm{~cm}$, especially at doses 120 and $180 \mathrm{~m}^{3}$ ha $^{-1}$ year $^{-1}$ [28]. The $\mathrm{pH}$ increase resulted on insoluble Al species, reducing the soil $\mathrm{H}+\mathrm{Al}$ content. Also, the exchangeable bases increase, which compete for exchange sites, can decrease $\mathrm{H}+\mathrm{Al}$ content [15]. The soil $\mathrm{pH}$ reduction in the $0-10$ and $10-20 \mathrm{~cm}$ layer in the treatment without manure application increased the potential acidity (Figure $2 \mathrm{~b}$ ) by $1.5 \mathrm{cmol}_{\mathrm{c}} \mathrm{dm}^{-3}$ for both depths.

The organic carbon (OC) content increased with DLM doses only in the depth 0-10 cm (Figure 2c). In this layer the 120 and $180 \mathrm{~m}^{3} \mathrm{ha}^{-1}$ year $^{-1}$ resulted in $11 \%$ and $12 \%$ higher OC compared to the control, respectively. This effect only in the $0-10 \mathrm{~cm}$ depth is due to the DLM application on the soil surface without revolving. The positive effect on OC with DLM application may be due to a direct action of carbon addition via manure or indirectly by increasing the $C$ addition via root and aerial biomass. Generally, greater increase occurs with increasing dose and years of application [5,31,32].

The phosphorus $(P)$ content increased with DLM application up to 20-30 cm (Figure 2d), with linear increment to $20 \mathrm{~cm}$ (Table 4). This $P$ increment in depth $(20-30 \mathrm{~cm})$ may be related to the presence of preferential channels, common in no-till fields. Other authors also observed $P$ increase with use of bovine manure, in superficial layers $(5 \mathrm{~cm})$ [31], as well as in deeper layers $(30 \mathrm{~cm})$ [32].

At $0-10 \mathrm{~cm}$ depth, the application of 120 and $180 \mathrm{~m}^{3} \mathrm{ha}^{-1}$ year ${ }^{-1}$ increased $141 \%$ and $217 \%$, respectively, the $\mathrm{P}$ content compared to the control. On the other hand, at $10-20 \mathrm{~cm}$ depth, this increase was $18 \%$ and $45 \%$ for the same doses. The effect of manure application was more evident in the surface layer $(0-10 \mathrm{~cm})$, what can be explained by the predominance of kaolinite, gibbsite, goethite and hematite mineral clays in the studied soil, and so, a high degree of P specific adsorption [34] decreasing the P mobility in depth. In addition, the soil management contributed to this, considering that in the no-tillage system the application of manure is on the soil surface without incorporation, and the mineral fertilizer is applied in-furrow at sowing with minimal soil disturbance. Furthermore, the increment in organic matter content increases negative charges, contributing to the reduction of $\mathrm{P}$ adsorption by repulsion [33]. Thus, in addition to the $\mathrm{P}$ additional supply to the soil by manure, another factor that may have contributed to the increase of available this nutrient content in the soil is the reduction in the fixation/adsorption of the applied $\mathrm{P}$ due to the organic matter increase (OC) in the $0-10 \mathrm{~cm}$ layer. It is noted that although the application of the highest DLM doses increases the $P$ content above the high interpreted level $\left(41-80 \mathrm{mg} \mathrm{kg}^{-1}\right)$ [15], the content is below the critical level (188 $\mathrm{mg}$ $\mathrm{kg}^{-1} \mathrm{P}$ for a Latossolo with sandy texture) [8]. If considered only the $\mathrm{P}$ supply from the organic source, the 
estimated average dose to be added would be $98 \mathrm{~m}^{3} \mathrm{ha}^{-1}$ year ${ }^{-1}$, being 124,84 and $87 \mathrm{~m}^{3} \mathrm{ha}^{-1}$ year ${ }^{-1}$, for maize, soybean and wheat, respectively. Therefore, an estimated manure dose for maximum yield would be approximately $300 \mathrm{~m}^{3} \mathrm{ha}^{-1}$ year ${ }^{-1}$ for maize, $220 \mathrm{~m}^{3}$ ha-1 $^{-1}$ year-1 for soybean and wheat, and $250 \mathrm{~m}^{3} \mathrm{ha}^{-1}$ year ${ }^{1}$ considering the crops average. Thus, it would be possible to reduce the need for mineral $\mathrm{P}$ application, maintaining the fertilization with the manure and reducing the production costs.

The DLM fertilization also increased the calcium (Ca) content up to $20 \mathrm{~cm}$ depth (Figure 2e), due to the supply of this element by the manure (average content 2.24 of $\mathrm{CaO}$ ). This effect was adjusted by regression to the linear function in both layers (Table 4), showing that for each $\mathrm{m}^{3}$ of manure added annually to the soil for nine years, there was an increase in exchangeable $\mathrm{Ca}$ of 0.023 and $0.010 \mathrm{cmol}_{\mathrm{c} \mathrm{dm}} \mathrm{da}^{-3}$ at layers $0-10$ and $10-20 \mathrm{~cm}$, respectively (Table 4). Other authors observed that each $\mathrm{m}^{3}$ of bovine manure added annually to the soil increased by $0.0113 \mathrm{cmol}_{\mathrm{c}} \mathrm{dm}^{-3} \mathrm{Ca}$ after a period of six years in the $0-5 \mathrm{~cm}$ layer [28]. In general, there is a greater increase of $\mathrm{Ca}$ in the superficial layer due to the high binding energy of $\mathrm{Ca}$ ions to negative colloid charges, especially in systems without revolving and with the application of fertilizers and acidity correctives on the soil surface. Probably, the high initial Ca content (5.6 $\mathrm{cmol}_{\mathrm{c}} \mathrm{dm}^{-3}$ in the $0-10 \mathrm{~cm}$ layer) [16] contributed to the vertical displacement of the nutrient, which is important to increase the deep root growth and, consequently, the nutrient and water supply to plants. Ca is essential in cell division and is absorbed practically all over the root hood and is considered immobile in the plant [35], so depth supply favors root growth.

Magnesium (Mg) content increased with DLM application up to $40 \mathrm{~cm}$ depth (Figure 2f); in the depths $10-20,20-30,30-40$ and $40-50 \mathrm{~cm}$ the increment was linear (Table 4). Similarly to $\mathrm{Ca}$, the increase of $\mathrm{Mg}$ is due to the addition by nine consecutive years of DLM (average content of $1.46 \mathrm{~g} \mathrm{~L}^{-1} \mathrm{MgO}$ ). $\mathrm{Mg}$ ions tend to move more easily in depth relative to $\mathrm{Ca}$ due to lower colloid binding energy. As in this study, others have verified that with the manure application occurs greater displacement of $\mathrm{Mg}$ in depth than $\mathrm{Ca}[28,30]$.

DLM application reduced the $\mathrm{Ca} / \mathrm{Mg}$ ratio up to $60 \mathrm{~cm}$ (Figure $2 \mathrm{~g}$ ). The manure increased the $\mathrm{Ca}$ and Mg contents, but the key element that determined the reduction of this relationship was the Mg, which had the largest increase in proportion, as well as had effect in deeper layers. Similarly, other authors verified reduction of $\mathrm{Ca} / \mathrm{Mg}$ ratio in layer $0-5 \mathrm{~cm}$ and $5-10 \mathrm{~cm}$ after six years of bovine manure application [36].

Potassium (K) contents increased linearly with the DLM application, and this effect was verified in all evaluated layers (Figure $2 \mathrm{~h}$ and Table 4). This effect was also verified by other authors after 25 years of bovine manure application [3]. The increment is due to the supply of this nutrient by DLM and mineral fertilizer, associated with the high initial $\mathrm{K}$ content $\left(0.3 \mathrm{cmol}_{\mathrm{c}} \mathrm{dm}^{-3}\right.$ in the $0-10$ layer $)$ [16] and the lower adsorption energy of this ion in relation to $\mathrm{Ca}$ and $\mathrm{Mg}$. Other authors observed increase in $\mathrm{K}$ content up to $80 \mathrm{~cm}$ after six years of liquid manure application $[31,36]$.

Base saturation (V\%) was affected by DLM application up to $30 \mathrm{~cm}$ depth (Figure 2i), adjusting for regression to the linear function in the 10-20, 20-30 and 40-50 cm layers (Table 4). These data were consistent with the increase in $\mathrm{Ca}, \mathrm{Mg}$ and $\mathrm{K}$ content provided by the DLM application, in addition to the reduction in potential acidity and the OC increase, which contributes to soil cation adsorption $[28,30,36]$. Other authors verified increase in $\mathrm{V} \%$ up to $10 \mathrm{~cm}$ [28], $12 \mathrm{~cm}$ [29] and $30 \mathrm{~cm}$ [37] after six, eight and eight years of bovine and swine application, respectively. During this experiment, two liming were carried out (in 2007 and 2013) and in the control treatment (without DLM application), the V\% reduced (Figure 2i), showing the acidification effect of mineral fertilization and base exportation. The application of DLM even in the lowest dose provided an increase of $\mathrm{V} \%$ and so, the acidification effect of the mineral fertilizers was neutralized, reducing the need for liming.

DLM application increased soil cation exchange capacity (CEC) up to $20 \mathrm{~cm}$ (Figure 2j), changing from medium to high in the $0-10 \mathrm{~cm}$ layer [16]. The increased OC content (Figure 2c) contributed to this DLM effect being verified moderate correlation $(r=0.58)$ between soil OC and CEC contents in the $0-10 \mathrm{~cm}$ layer. The increase in soil CEC favors the adsorption of cations added to the soil by manure and mineral fertilizers, such as $\mathrm{K}, \mathrm{Ca}$ and $\mathrm{Mg}$ [37].

\section{Main soil chemical variables that influenced grain yield}

The principal component analysis (PCA) was carried out between accumulated grain yield and soil chemical variables in the $0-10 \mathrm{~cm}$ layer, considering that in this layer there was a greater change in the soil chemical variables as a function of DLM application. The increase in accumulated yield was due to the improvement in all evaluated chemical variables, and components 1 and 2 represented approximately $80 \%$, 
$77 \%, 78 \%$ and $78 \%$ of the ability to explain the covariance of the variables for maize, soybean, wheat and total, respectively (Figure 3).

For maize, there was a high positive correlation between accumulated yield and $\mathrm{P}$ (Figure 3a), while for soybean and wheat, the base complex was mainly responsible for high yield (Figure $3 b$ and Figure c). In PCA carried out for accumulated total grain yield it was observed that, besides the bases, the micronutrients $\mathrm{Zn}$ and $\mathrm{Mn}$ were highly associated with higher yield (Figure 3d). Except for maize, in all PCA, Ca/Mg ratio and potential acidity $(\mathrm{H}+\mathrm{Al})$ were negatively correlated with accumulated yield. In generally, the dispersion of the observations followed the treatment standard.

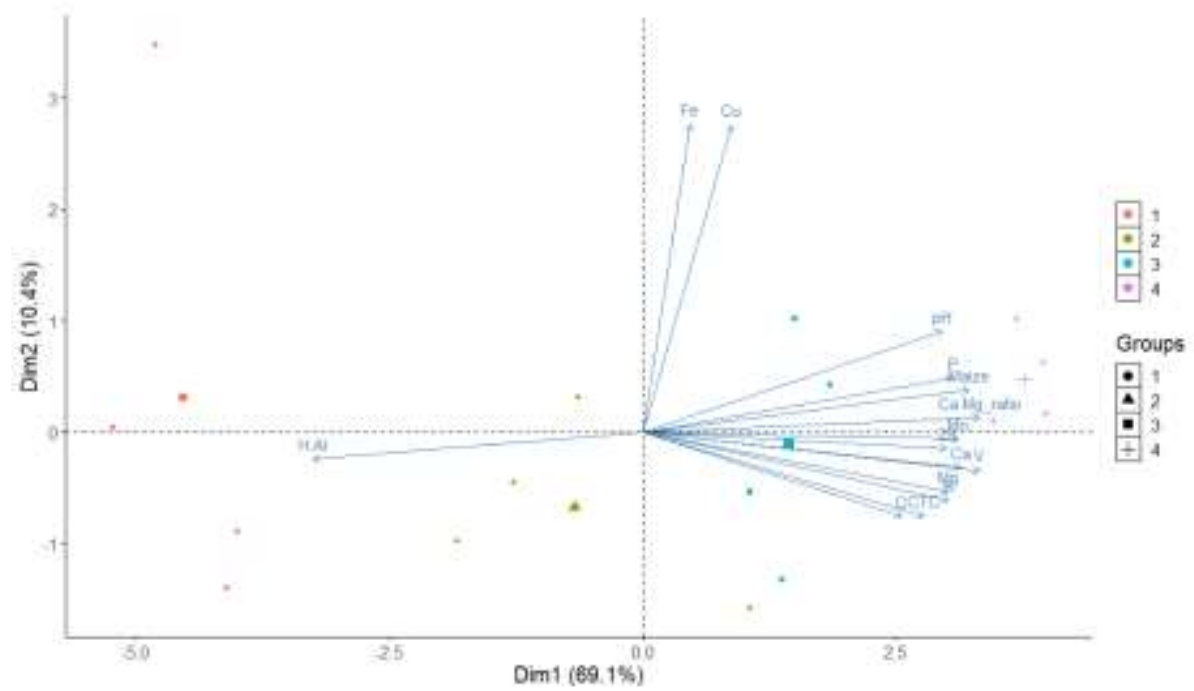

(a)

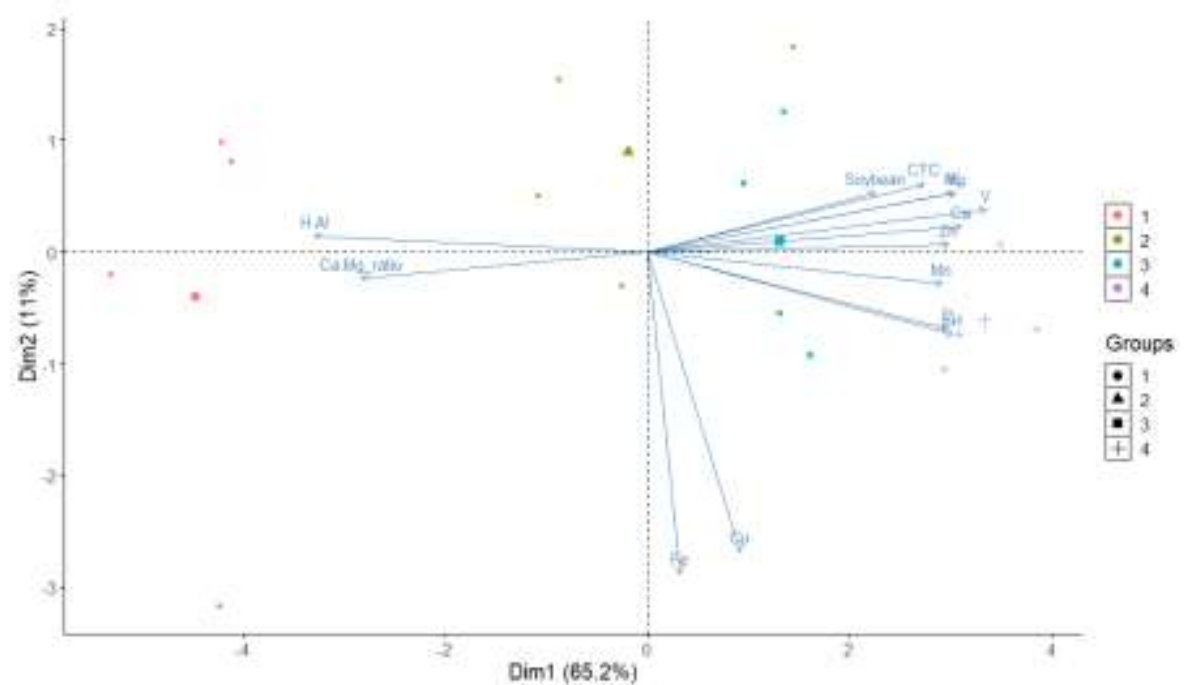

(b) 


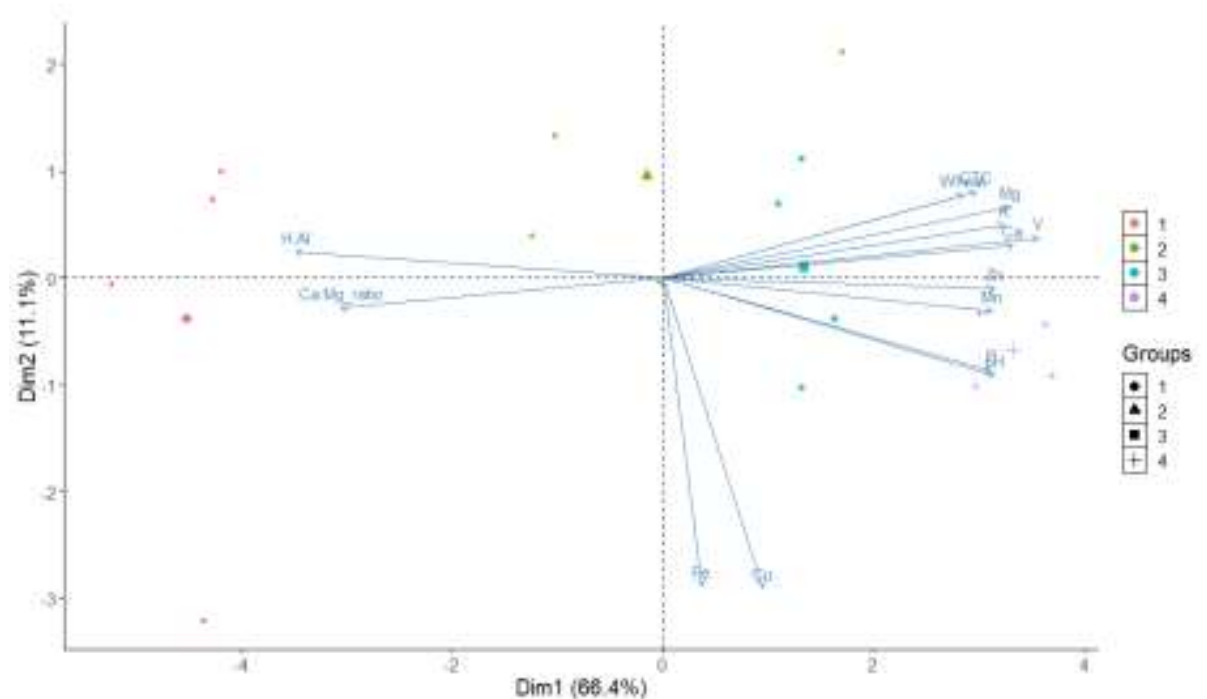

(c)

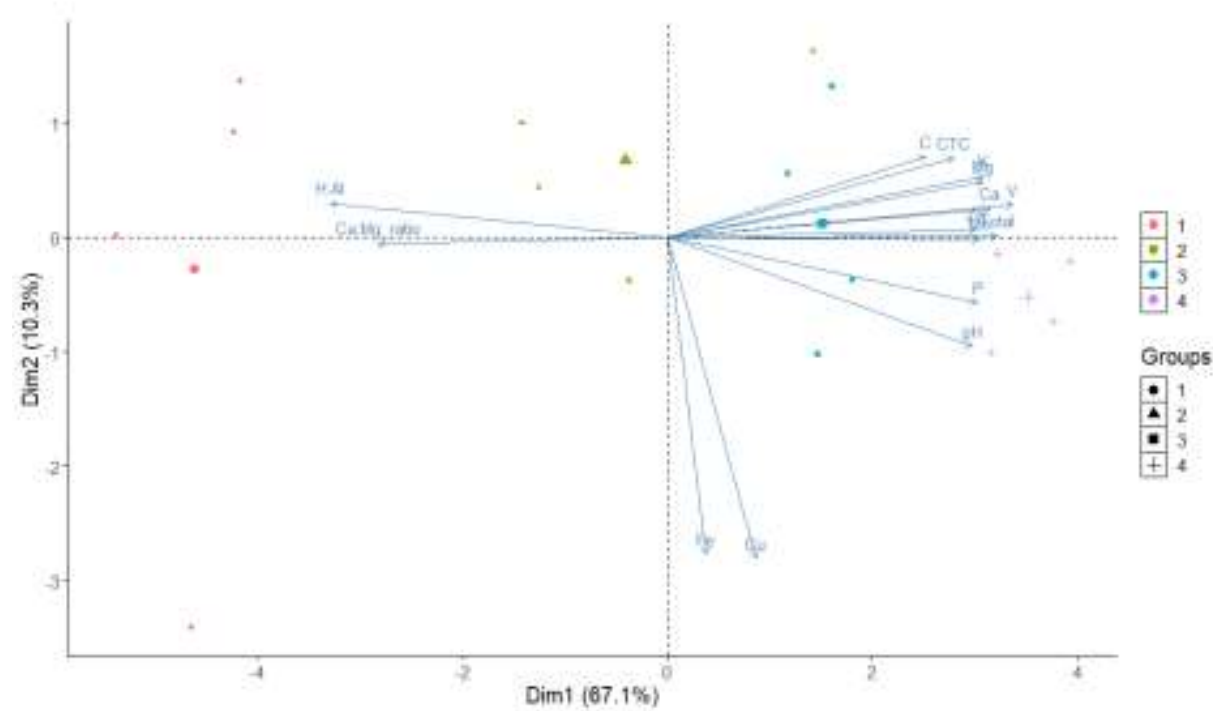

(d)

Figure 3. Principal component analysis (PCA) of soil chemical attributes and maize yield (a); soybean (b); wheat (c); and total (maize + soybean + wheat) (d), in the $0-10 \mathrm{~cm}$ depth, after nine years of application of $0,60,120$ and $180 \mathrm{~m}^{3}$ ha $^{-1}$ year $^{-1}$ of dairy liquid manure under no-tillage, in Latossolo Bruno Distrófico típico.

\section{CONCLUSION}

The DLM application complementary the mineral fertilization increase soybean, wheat and maize grain yield under no-tillage, with a best average dose for all crops of $150 \mathrm{~m}^{3} \mathrm{ha}^{-1}$ year ${ }^{-1}$. Among the crops, maize has a linear response, since soybean and wheat has a maximum dose recommended.

The DLM improve all soil chemical variables, and even applied on the soil surface it improve the soil chemical variables in deep layers.

The crop yield increment is not attributed to a single variable, but the improvement of all soil chemical variables, however, the results suggest that the balance between the exchangeable bases and the acidity of the soil exchange complex is fundamental for maximum expression of the productive potential.

Funding: This research received no external funding.

Acknowledgments: The authors are grateful to Foundation to Support the Scientific and Technological Development of Paraná State (Araucaria Foundation), National Council for Scientific and Technological Development (CNPq), Coordination for the Improvement of Higher Education Personnel (CAPES) for the financial support and grants and to ABC Research Foundation for the field support.

Conflicts of Interest: The authors declare no conflict of interest. 


\section{REFERENCES}

1. IBGE. Produção da Pecuária Municipal. Rio de Janeiro: Instituto Brasileiro de Geografia e Estatística; 2016. 53 p.

2. Kapkiyai JJ, Karanja NK, Qureshi JN, Smithson PC, Woomer PL. Soil organic matter and nutrient dynamics in a Kenyan Nitisol under long-term fertilizer and organic input management. Soil Biology and Biochemistry. 1999 Nov; 31(13):1773-82.

3. Hao X, Chang $C$. Does long-term heavy cattle manure application increase salinity of a clay loam soil in semi-arid southern Alberta? Agriculture, Ecosystems and Environment. 2003 Jan; 94(1):89-103.

4. Mellek JE, Dieckow J, Silva VL, Favaretto N, Pauletti V, Vezzani FM, Souza JLM. Dairy liquid manure and notillage: physical and hydraulic properties and carbon stocks in a Cambissol of Southern Brazil. Soil and Tillage Research. 2010 Set; 110(1):69-76.

5. Bhattacharyya R, Prakash V, Kundu S, Srivastva AK, Gupta HS, Mitra S. Long term effects of fertilization on carbon and nitrogen sequestration and aggregate associated carbon and nitrogen in the Indian sub-Himalayas. Nutrient Cycling in Agroecosystems. 2010; 86(1):1-16.

6. Abedi T, Alemzadeh A, Kazemeini A. Effect of organic and inorganic fertilizers on grain yield and protein banding pattern of wheat. Australian Journal of Crop Science. 2010; 4(6):384-9.

7. Chivenge $P$, Vanlauwe $B$, Six J. Does the combined application of organic and mineral nutrient sources influence maize productivity? A meta-analysis. Plant and Soil. 2011; 342(1):1-30.

8. Abboud FY, Favaretto N, Motta ACV, Barth G, Goulart GD. Phosphorus mobility and degree of saturation in Oxisol under no-tillage after long-term dairy liquid manure application. Soil and Tillage Reseacrh. 2018 Apr; 117(1):45-53.

9. Mamia A, Amin AKMR, Roy TS, Faruk GM. Influence of inorganic and organic fertilizers on growth and yield of soybean. Bangladesh Agronomy Journal. 2018; 21(1):77-81.

10. Hao XJ, Zhang TQ, Tan CS, Welacky T, Wang YT, Lawrence D, Hong JP. Crop yield and phosphorus uptake as affected by phosphorus-based swine manure application under long-term corn-soybean rotation. Nutrient Cycling in Agroecosystems. 2015; 103(1):217-28.

11. Embrapa. Sistema Brasileiro de Classificação de Solos. 5rd ed. Brasília: Embrapa; 2018. 356 p.

12. Caviglione JH, Kiihl LRB, Caramori PH, Oliveira D. Cartas Climáticas do Paraná. Londrina: Iapar; 2000.

13. Timofiecszyk A. Perda de solo, água e nutrientes com aplicação de dejeto líquido bovino sob plantio direto e chuva natural em Latossolo Bruno [dissertação]. Curitiba: Universidade Federal do Paraná; 2009. 72 p.

14. Abboud FY. Mobilidade de nutrientes no perfil do solo em plantio direto com aplicação de dejeto líquido bovino em longo prazo [dissertação]. Curitiba: Universidade Federal do Paraná; 2016. 64 p.

15. Raij Bvan, Cantarella H, Quaggio JÁ, Furlani ÂMC. Recomendações de adubação e calagem para o estado de São Paulo. 2rd ed. Campinas: Instituto Agronômico; 1997. 285 p.

16. NEPAR. Manual de adubação e calagem para o estado do Paraná. 2rd ed. Curitiba: Sociedade Brasileira de Ciência do Solo; 2019. 289 p.

17. Raij Bvan, Quaggio JÁ. Métodos de análise de solo para fins de fertilidade. 1rd ed. Campinas: Instituto Agronômico; 1983. $39 \mathrm{p}$.

18. Pauletti V, Barcellos M, Motta ACV, Monte Serrat B, Santos IR. Produtividade de culturas sob diferentes doses de esterco líquido de gado de leite e de adubo mineral. Scientia Agraria. 2008; 9(2):199-205.

19. Brar BS, Singh J, Singh G, Kaur G. Effects of long term application of inorganic and organic fertilizers on soil organic carbon and physical properties in maize-wheat rotation. Agronomy. 2015; 5(1):220-38.

20. Menezes JFS, Berti MPS, Vieira Junior VD, Ribeiro RL, Berti CLF. Extração e exportação de nitrogênio, fósforo e potássio pelo milho adubado com dejetos de suínos. Revista de Agricultura Neotropical. 2018 Jul; 5(3):55-9.

21. Sartor LR, Assmann AL, Assmann TS, Bigolin PE, Miyazawa M, Carvalho PCF. Effect of swine residue rates on corn, common bean, soybean and wheat yield. Revista Brasileira de Ciência do Solo. 2012 Mar; 36(2):661-9.

22. Baghdadi A, Halim RA, Ghasemzadeh A, Ramlan MF, Sakimin SZ. Impact of organic and inorganic fertilizers on the yield and quality of silage corn intercropped with soybean. Peer Journal. 2018 Oct; 6(1):2-26.

23. Sheoran S, Raj D, Antil RS, Mor VS, Dahiya DS. Productivity, seed quality and nutrient use efficiency of wheat (Triticum aestivum) under organic, inorganic and integrated nutrient management practices after twenty years of fertilization. Cereal Research Communications. 2017; 45(1):315-25.

24. Ceretta CA, Durigon R, Basso CJ, Barcellos LAR, Vieira FCB. Características químicas de solo sob aplicação de esterco líquido de suínos em pastagem natural. Pesquisa Agropecuária Brasileira. 2003 Jun; 36(6):729-35.

25. Zagonel J, Fernandes EC. Doses e épocas de aplicação de redutor de crescimento afetando cultivares de trigo em duas doses de nitrogênio. Planta Daninha. 2007; 25(2):331-9. 
26. Kundu S, Bhattacharyya R, Prakash V, Gupta HS, Pathak H, Ladha JK. Long-term yield trend and sustainability of rainfed soybean-wheat system through farmyard manure application in a sandy loam soil of the Indian Himalayas. Biology and Fertility of Soils. 2007; 43(1):271-80.

27. Whalen JK, Chang C, Clayton GW, Carefoot JP. Cattle manure amendments can increase the pH of acid soils. Soil Science Society of America Journal. 2000 May; 64(1):962-6.

28. Silva JCPM, Motta ACV, Pauletti V, Favaretto N, Barcellos M, Oliveira AS, Veloso CM, Silva LFC. Esterco líquido de bovinos leiteiros combinado com adubação mineral sobre atributos químicos de um Latossolo Bruno. Rev. Bras.Cienc. Solo. 2008; 32:2563-72.

29. Lourenzi CR, Ceretta CA, Silva LS, Tentin G, Girotto E, Lorensini F, Tiecher TL, Brunetto G. Soil chemical properties related to acidity under successive pig slurry applications. Rev. Bras. Cienc. Solo. 2011; 35:1827-36.

30. Lourenzi CR, Scherer EE, Ceretta CA, Tiecher TL, Cancian A, Ferreira PAA, Brunetto G. Atributos químicos de Latossolo após sucessivas aplicações de composto orgânico de dejeto líquido de suínos. Pesq. Agropec.Bras. 2016 Mar; 51(3):233-42.

31. Silva JCPM, Motta ACV, Pauletti V, Veloso CM, Favaretto N, Barcellos M, Oliveira AS, Silva LFC. Esterco de gado leiteiro associado a adubação mineral e sua influência na fertilidade de um Latossolo sob plantio direto. Rev. Bras. Cienc. Solo. 2010; 34:453-63.

32. Maillard É, Angers DA, Chantigny M, Lafond J, Pageau D, Rochette P, Lévesque G, Leclerc M-L, Parent L-É. Greater accumulation of soil organic carbon after liquid dairy manure application under cereal-forage rotation than cereal monoculture. Agriculture, Ecosystems and Environment. 2016; 233:171-8.

33. Singh M, Reddy KS, Singh VP, Rupa TR. Phosphorus availability to rice (Oriza sativa L.) - wheat (Triticum aestivum L.) in a Vertisol after eight years of inorganic and organic fertilizer additions. Bioresource Technology. 2007; 98:1474-81.

34. Vilar CC, Costa ACS, Hoepers A, Junior IGS. Capacidade máxima de adsorção de fósforo relacionada a formas de ferro e alumínio em solos subtropicais. Rev. Bras. Cienc. Solo. 2010; 34:1059-68.

35. Hawkesford M, Horst W, Kichey T, Lambers H, Schjoerring J, Møller IS, White P. Functions of macronutrients. 3nd ed. In: Marschner P, editor. Mineral nutrition of higher plants. London: Elsevier; 2012. p. 135-89.

36. Barcellos M, Motta ACV, Pauletti V, Silva JCPM, Barbosa JZ. Atributos químicos de Latossolo sob plantio direto adubado com esterco de bovinos e fertilizantes minerais. Communicata Scientiae. 2015; 6(3):263-73.

37. Brunetto G, Comin JJ, Schmitt DE, Guardini R, Mezzari CP, Oliveira BS, Moraes MP, Gatiboni LC, Lovato PE, Ceretta CA. Changes in soil acidity and organic carbon in a sandy typic Hapludalf after medium-term pig-slurry and deep-litter application. Rev. Bras. Cienc. Solo. 2012; 36:1620-8.

2020 by the authors. Submitted for possible open access publication under the terms and conditions of the Creative Commons Attribution (CC BY NC) license (https://creativecommons.org/licenses/by-nc/4.0/). 